\title{
CORRESPONDENCE
}

\section{I.U.G.S./I.G.C.P. Precambrian-Cambrian Boundary Working Group in Normandy and Paris, 1974}

SIR - We offer to your readers an account of the International Precambrian/Cambrian Boundary Working Group's excursion to Normandy and Brittany and conference in Paris in June of 1974.

1. Date and place of meeting: 5-15 June 1974

(a) Normandy and Brittany: field excursion studying Brioverian and Cambrian between Caen, the Cotentin and Rennes. 5-9 June.

(b) Paris Conference: Institute of Palaeontology, National Museum of Natural History, 5 Place Valhubert, Paris V'. 10-15 June.

2. Number of participants and countries represented:

(a) Normandy and Brittany field excursion: Dr J. W. Cowie, England; Dr A. Yu. Rozanov, U.S.S.R.; Dr K. O. Bjørlykke, Norway; Dr A. Boudda, Morocco; Dr G. Choubert, France; Dr B. Daily, Australia; Prof. A. R. Palmer, U.S.A.; Acad. B. S. Sokolov, U.S.S.R.; Dr F. Debrenne, France; M. M. Debrenne, France; Dr A. Faure-Muret, France; Prof. F. Doré, France; Dr LeGall, France.

(b) Paris Conference: the above participants who were in Normandy, plus Prof. M. F. Glaessner, Australia; Mr W. B. Harland, England; Prof. P. Hupé, France; Dr A. W. A. Rushton, England; Dr Menchikoff, France; Dr Leman, France; Dr Marçays, UNESCO.

3. Objectives of the meeting

(a) The principles to be adopted in correlating and selecting the international Boundary Stratotype.

(b) Different aspects of the Boundary in different parts of the world - Australia, India, North America, East Greenland, Wales, Norway, U.S.S.R., France, Morocco.

(c) A general discussion on the Boundary's global correlation and its principles.

4. Results and decisions

Professor Leman opened the conference, Dr Menchikoff outlined the history of research to date and Dr Marçays discussed the relationships between the Working Group and international organisations such as UNESCO and IUGS.

(1) The Chairman's Introduction

The actual method of selection of a suitable boundary stratotype point was discussed and the objectives of the conference were re-emphasized:

(a) an assessment of the criteria to guide the selection,

(b) review of suitable regions,

(c) programme of work until 1980.

A brief review was given of the steps in the international work on the Precambrian-Cambrian Boundary from the 1956 International Geological Congress in Mexico to date. The relationships between the Working Group and other organizations such as I.G.C.P., the International Commission on Stratigraphy and the International Subcommission on Stratigraphical Classification were outlined. The adoption of the work programme of the Precambrian-Cambrian Boundary Working Group as a key project under IUGS-UNESCO as a part of the IGCP programme was warmly welcomed. A plea for the enlistment of the support of all interested geologists was made.

In conclusion a progress report by Professor Glaessner and J. W. Cowie on

Geol. Mag. 112 (2), 1975, pp. 197-198. Printed in Great Britain. 
the Precambrian-Cambrian Boundary Problem was presented by the Chairman as a basis for discussion.

(2) 'The Precambrian-Cambrian faunal sequence in the Northern Territory, Australia and South Australia,' B. DAILY.

(3) 'The Precambrian-Cambrian boundary in Central Australia,' M. F. Glaessner.

(4) The Indian IGCP proposal was outlined by the Chairman.

(5) 'The division of latest Precambrian time,' W. B. HaRLand.

(6) 'Ediacaran, Phanerozoic, Palaeozoic and Cambrian,' A. R. PALmer.

(7) 'Possible North American stratotypes,' A. R. PALmer.

(8) 'East Greenland: Ella Island,' J. W. CowtE.

(9) 'Wales: ??Tommotian fossil in Wales,' A. W. A. Rushton.

(10) 'Stratigraphy of late Precambrian and early Palaeozoic rocks of Norway, K. O. BJøRLYKKE.

(11) 'Vendian life and the Precambrian-Cambrian Boundary in the U.S.S.R,' B. S. SOKOLOV.

(12) 'Borehole information from Isit and Saylyk, east Siberia,' B. S. SokoLov.

(13) 'General problems and principles for the placing of the Precambrian-Cambrian Boundary,' A. YU. Rozanov.

(14) 'Carbonate rocks from Ulakhan-Sulugur and other sections on the River Aldan, east Siberia,' A. Yu. Rozanov.

(15) 'What is the range of the Fallotaspis zone?' A. Yu. Rozanov.

(16) 'Reports on the excursions of members of the Working Group to Morocco in May 1974 and to Normandy and Brittany just prior to the conference in Paris,' A. Boudda, G. Choubert, F. Debrenne, A. Faure-Muret and LeGall.

It was agreed unanimously that:

(i) The primary task of the Working Group was the choice of a stratotype boundary point and that a secondary task was the consideration of associated stratigraphic divisions above and below the boundary.

(ii) That any succession selected for the Boundary Point must be as continuous as possible, marine, as monofacial as possible and that the main method of guidance in selection should be biostratigraphy but all possible methods of correlation should be enlisted.

(iii) The 'Ediacara' type fauna should be considered Precambrian.

(iv) The 'Olenellid/Fallotaspid' trilobite faunas should be considered as Cambrian.

(v) Between (iii) and (iv) are fossiliferous successions the allocation of which to Precambrian or Cambrian is uncertain and/or undecided and their study is the suggested focus of the Working Group's attention.

\section{Planned activity in the near future}

The joint activity of the Polish-Soviet specialists on the Precambrian-Cambrian Boundary is considered by the Working Group to be a positive and useful experience. The Working Group hopes that the results of this work will be discussed at a later meeting, with the participation of members and corresponding members of the Working Group who have taken part.

(1) October/November 1975 - a small field excursion for 3 weeks in Morocco.

(2) July/August 1976: (a) Special field excursion in Australia, (b) Symposium on the boundary and business meetings of the Working Group during the Australian International Geological Congress.

6. Further work by members of the Group in Morocco, the U.S.S.R., India, the U.S.A. and elsewhere, leading up to a final report to the International Geological Congress in 1980 was discussed.

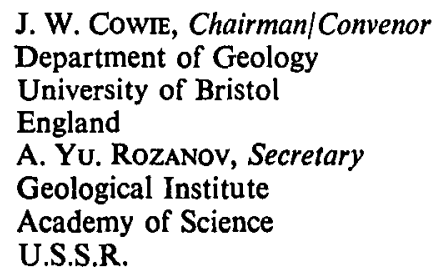

